\title{
PENILAIAN TINGKAT TEKNOLOGI GALANGAN KAPAL PT. PROSKUNEO KADARUSMAN MUARA BARU JAKARTA
}

\section{Assessment of Technology Levels PT. Proskuneo Kadarusman Shipyard Muara Baru Jakarta}

Oleh:

Izza M Apriliani ${ }^{1}$, Mohammad Imron ${ }^{2}$, Vita Rumanti Kurniawati ${ }^{2}$

${ }^{1}$ Departemen Perikanan, Fakultas Perikanan dan Ilmu Kelautan, Universitas Padjadjaran

${ }^{2}$ Departemen Pemanfaatan Sumberdaya Perikanan, FPIK-IPB

Korespondensi:izza.mahdiana@unpad.ac.id

\begin{abstract}
ABSTRAK
Peningkatan jumlah kapal di PPS Nizam Zachman akan menjadi target potensial pasar bagi galangan yang ada di sekitar pelabuhan. Salah satu galangan kapal yang berperan dalam melayani kapalkapal di sekitar PPS Nizam Zachman adalah PT. Proskuneo Kadarusman. Oleh karena itu, untuk dapat memenuhi permintaan pasar yang meningkat, PT. Proskuneo Kadarusman harus dapat mengimbangi dengan meningkatkan produktivitas dan daya saing. Upaya meningkatkan produktivitas galangan salah satunya dengan cara meningkatkan teknologi. Peningkatan teknologi perlu didahului dengan penilaian terhadap tingkat teknologi. Penilaian tingkat teknologi dilakukan dengan menghitung nilai TCC (technology contribution coefficient) dari komponen teknologi technoware, humanware, infoware dan orgaware (organisasi). Penelitian ini dilaksanakan pada bulan Agustus 2011 dengan menggunakan metode studi kasus di PT. Proskuneo Kadarusman Muara Baru Jakarta. Analisis data yang digunakan adalah analisis TCC dengan menilai kontribusi komponen teknologi. Galangan PT. Proskuneo Kadarusman merupakan salah satu galangan yang aktif melayani reparasi dan produksi kapal dengan memiliki manajemen galangan yang baik yang meliputi struktur organisasi, sumberdaya manusia, pelayanan reparasi dan produksi serta sistem informasi internal dan eksternal. Nilai kontribusi komponen humanware memiliki nilai kontribusi tetinggi sedangkan komponen infoware memiliki kontribusi terendah. Nilai TCC dari galangan kapal PT. Proskuneo Kadarusman menunjukkan teknologi di galangan tersebut berada pada level semi-modern.
\end{abstract}

Kata kunci: humanware, infoware, technoware, teknometrik, orgaware

\section{ABSTRACT}

Increasing number of ships in the PPS Nizam Zachman will increasing potential target market for shipyards around the port. One of the shipyards that plays a role in servicing ships at PPS Nizam Zachman is PT. Proskuneo Kadarusman. Therefore, in order to meet increasing market demand, PT. Proskuneo Kadarusman must be able to compensate by increasing productivity and competitiveness. One of the efforts to increase shipyard productivity is by increasing technology. Technology improvement needs to be preceded by an assessment of the level of technology. Technology level assessment is carried out by calculating the value of technology contribution coefficient (TCC) from the technology component of technoware, humanware, infoware and orgaware (organization). This research was conducted in August 2011 using the case study method at PT. Proskuneo Kadarusman Muara Baru Jakarta. Analysis of the data used is TCC analysis by assessing the contribution of technology components. PT. Proskuneo Kadarusman is one of the active shipyards serving ship repair and production by having a good shipyard management which includes organizational structure, human resources, repair and production services as well as internal and external information systems. 
The contribution value of the humanware component has the highest contribution value while the infoware component has the lowest contribution. TCC value of PT. Proskuneo Kadarusman shows that the technology at the shipyard is at a semi-modern level.

Key words: humanware, infoware, technoware, technometric, orgaware

\section{PENDAHULUAN}

Galangan kapal merupakan suatu industri yang menghasilkan keluaran (output) berupa kapal, bangunan lepas pantai atau alat-alat apung lainnya (Widjaja, 1996). Mutu keterampilan dan pengalaman serta dukungan sejumlah mesin dan peralatan dengan teknologi merupakan faktor-faktor utama yang berpengaruh dalam kekuatan dan kemampuan kapal yang diproduksi oleh galangan kapal.

Galangan kapal di Indonesia memiliki ciri khas tersendiri dalam pembuatan kapal. Hal ini berdasarkan tujuan pembuatan kapal dan teknologi yang tersedia di galangan. Berdasarkan tujuannya kapal dapat dibedakan menjadi kapal perikanan dan kapal pengangkut. Berdasarkan teknologinya, dapat dibedakan menjadi kapal yang dibangun dengan teknologi modern dan tradisional. Dengan demikian setiap galangan kapal memiliki kualitas dan kemampuan produksi yang berbeda-beda.

Secara garis besar pembangunan kapal perikanan di galangan kapal Indonesia terdiri dari cara tradisional dan cara modern. Galangan kapal dengan cara tradisional mengandalkan kemampuan yang diturunkan secara tradisi dan turun menurun serta tidak memiliki perencanaan umum dalam proses produksinya. Sementara itu, galangan kapal dengan cara modern telah menggunakan perencanaan pembuatan sesuai dengan acuan perkapalan yang berlaku di Indonesia.

Muara baru merupakan salah satu pusat kegiatan perikanan daerah Jakarta yang terletak di Jakarta bagian utara. Muara baru ini menjadi pusat kegiatan perikanan laut yakni dengan adanya Pelabuhan Perikanan Samudera (PPS) Nizam Zachman yang memiliki fasilitas pendukung termasuk galangan kapal di sekitar pelabuhan. Berdasarkan data aktivitas kapal di PPS Nizam Zachman tahun 2007 sampai 2010, jumlah kapal yang melakukan kegiatan tambat labuh terus meningkat (KKP 2010). Dengan demikian peningkatan jumlah kapal akan menjadi target potensial pasar bagi galangan yang ada di sekitar PPS Nizam Zachman. Salah satu galangan kapal yang berperan dalam melayani kapalkapal di sekitar PPS Nizam Zachman adalah PT. Proskuneo Kadarusman. Oleh karena itu, untuk dapat memenuhi permintaan pasar yang meningkat, PT. Proskuneo Kadarusman harus dapat mengimbangi dengan meningkatkan produktivitas dan daya saing. Upaya meningkatkan produktivitas galangan salah satunya dengan cara meningkatkan teknologi.

Peningkatan teknologi perlu didahului dengan penilaian terhadap tingkat teknologi. Saat ini, penilaian tentang tingkat teknologi pada galangan PT. Proskuneo Kadarusman belum dilakukan. Berdasarkan hal-hal tersebut, maka perlu dilakukan penilaian tingkat teknologi pada galangan kapal PT. Proskuneo Kadarusman. Penilaian tingkat teknologi berguna untuk mengetahui sejauh mana tingkat teknologi yang mencakup komponen humanware, technoware, infoware dan orgaware dalam pembuatan dan perbaikan kapal pada galangan kapal tersebut. Dengan demikian, pihak galangan dapat mengidentifikasi komponen teknologi mana yang paling tepat sebagai sasaran pengembangan teknologi demi kemajuan galangan kapal tersebut.

\section{METODE PENELITIAN}

Penelitian dilakukan pada bulan Agustus 2011-April 2012. Lokasi penelitian adalah galangan kapal PT. Proskuneo Kadarusman Muara Baru, Jakarta. Alat yang digunakan dalam penelitian ini berupa kuisioner dan kamera digital. 
Penelitian dilakukan dengan menggunakan metode studi kasus. Menurut Hasan (2002) studi kasus merupakan penelitian mengenai suatu objek penelitian yang berkenaan dengan suatu fase spesifik atau khas dari keseluruhan personalitas. Tujuan dari studi kasus ini adalah memberikan gambaran secara mendetail tentang latar belakang, sifat-sifat serta karakter yang khas dari kasus yang kemudian hasilnya dijadikan suatu hal yang bersifat umum. Kasus yang dikaji dari penelitian ini adalah tingkat teknologi pada galangan PT. Proskuneo Kadarusman Muara Baru Jakarta.

Jenis data terdiri atas data primer dan data sekunder. Data primer berupa keadaan umum galangan kapal dan data komponen teknologi galangan kapal dengan teknik pengamatan dan wawancara dengan kuisioner. Data sekunder berupa kajian pustaka dari sumber relevan. Data yang diperoleh akan dianalisis dengan analisis TCC (Technologi Contibution Coefficient). Kriteria komponen teknologi mengacu pada kriteria yang digunakan oleh Wiraatmaja dan Ma'ruf (2004) yaitu komponen technoware (fasilitas rekayasa), humanware (kemampuan manusia), infoware (informasi) dan orgaware (organisasi).

Tabel 1 Kriteria pemberian skor derajat kecanggihan komponen teknologi

\begin{tabular}{|c|c|c|c|c|}
\hline \multicolumn{4}{|c|}{ Derajat Kecanggihan Komponen Teknologi } & \multirow{2}{*}{ Skor } \\
\hline Technoware & Humanware & Infoware & Orgaware & \\
\hline $\begin{array}{l}\text { Fasilitas manual } \\
\text { (manual facilities) }\end{array}$ & $\begin{array}{l}\text { Kemampuan } \\
\text { mengoperasikan } \\
\text { (operating } \\
\text { abilities) } \\
\end{array}$ & $\begin{array}{l}\text { Fakta pengenalan } \\
\text { (familianzing } \\
\text { facts) }\end{array}$ & $\begin{array}{l}\text { Kerangka kerja } \\
\text { usaha (striving } \\
\text { frameworks) }\end{array}$ & 123 \\
\hline $\begin{array}{l}\text { Fasilitas tenaga } \\
\text { penggerak (power } \\
\text { facilities) }\end{array}$ & $\begin{array}{l}\text { Kemampuan } \\
\text { memasang } \\
\text { (setting-up } \\
\text { abilities) }\end{array}$ & $\begin{array}{l}\text { Fakta penguraian } \\
\text { (describing facts) }\end{array}$ & $\begin{array}{l}\text { Kerangka kerja } \\
\text { ikatan (tie-up } \\
\text { frameworks) }\end{array}$ & 234 \\
\hline $\begin{array}{l}\text { Fasilitas serbaguna } \\
\text { (general purpose } \\
\text { facilities) }\end{array}$ & $\begin{array}{l}\text { Kemampuan } \\
\text { mereparasi } \\
\text { (repairing } \\
\text { abilities) }\end{array}$ & $\begin{array}{l}\text { Fakta } \\
\text { pengkhususan } \\
\text { (specifying fact) }\end{array}$ & $\begin{array}{l}\text { Kerangka kerja } \\
\text { bertindak berani } \\
\text { (venturing } \\
\text { frameworks) }\end{array}$ & 345 \\
\hline $\begin{array}{l}\text { Fasilitas } \\
\text { penggunaan } \\
\text { khusus (special } \\
\text { purpose facilities) }\end{array}$ & $\begin{array}{l}\text { Kemampuan } \\
\text { reproduksi } \\
\text { (reproducing } \\
\text { abilities) }\end{array}$ & $\begin{array}{l}\text { Fakta } \\
\text { penggunaan } \\
\text { (utilizing facts) }\end{array}$ & $\begin{array}{l}\text { Kerangka kerja } \\
\text { proteksi } \\
\text { (protecting } \\
\text { frameworks) }\end{array}$ & 456 \\
\hline $\begin{array}{l}\text { Fasilitas } \\
\text { otomatisasi } \\
\text { (automatic } \\
\text { facilities) }\end{array}$ & $\begin{array}{l}\text { Kemampuan } \\
\text { mengadaptasi } \\
\text { (adaptation } \\
\text { abilities) }\end{array}$ & $\begin{array}{l}\text { Fakta } \\
\text { pemahaman } \\
\text { (comprehending } \\
\text { facts) }\end{array}$ & $\begin{array}{l}\text { Kerangka kerja } \\
\text { stabilitasi } \\
\text { (stabiling } \\
\text { frameworks) }\end{array}$ & 567 \\
\hline $\begin{array}{l}\text { Fasilitas } \\
\text { terkomputerisasi } \\
\text { (computerized } \\
\text { facilities) }\end{array}$ & $\begin{array}{l}\text { Kemampuan } \\
\text { mengembangkan } \\
\text { (improving } \\
\text { abilities) }\end{array}$ & $\begin{array}{l}\text { Fakta } \\
\text { pembiasaan } \\
\text { (generalizing } \\
\text { facts) }\end{array}$ & $\begin{array}{l}\text { Kerangka kerja } \\
\text { perluasan } \\
\text { cakrawala } \\
\text { (prospecting } \\
\text { frameworks) }\end{array}$ & 678 \\
\hline $\begin{array}{l}\text { Fasilitas integrasi } \\
\text { (integrated } \\
\text { facilities) }\end{array}$ & $\begin{array}{l}\text { Kemampuan } \\
\text { inovasi } \\
\text { (innovation } \\
\text { abililities) }\end{array}$ & $\begin{array}{l}\text { Fakta pengkajian } \\
\text { (assessing facts) }\end{array}$ & $\begin{array}{l}\text { Kerangka kerja } \\
\text { memimpin } \\
\text { (leading } \\
\text { frameworks) }\end{array}$ & 789 \\
\hline
\end{tabular}

Sumber: Wiratmaja dan Ma'ruf, 2004 
Terdapat lima langkah untuk mengestimasi nilai TCC (Nazaruddin 2008), yaitu (1) estimasi derajat kecanggihan, (2) pengkajian state of the art, (3) penentuan kontribusi komponen, (4) pengkajian intensitas kontribusi komponen, dan (5) perhitungan TCC. Nilai TCC dari suatu perusahaan menunjukkan kontribusi teknologi dari operasi transformasi total terhadap output.

Nilai derajat kecanggihan menunjukkan kecanggihan dari setiap komponen teknologi yang ada di galangan. Estimasi derajat kecanggihan dilakukan dengan mengacu pada salah satu prosedur yang diusulkan UN-ESCAP (1989). Untuk lebih jelasnya, prosedur tersebut disajikan pada Tabel 1.

State of the art (SOTA) adalah tingkat kompleksitas dari masing-masing komponen teknologi. Sebelum dilakukan pengkajian terhadap rating SOTA setiap komponen, terlebih duhulu dilakukan penilaian terhadap masing-masing kriteria pada setiap komponen teknologi.

Tabel 2 Matriks penilaian kriteria komponen technoware

\begin{tabular}{|c|c|c|c|}
\hline No. & Kriteria Komponen Technoware & Keterangan & Skor \\
\hline 1 & Tipe mesin yang digunakan & Manual (0); mekanik (5); otomatis (10) & \\
\hline 2 & Tipe proses yang diterapkan & $\begin{array}{l}\text { Sederhana: hanya satu operasi diterapkan } \\
\text { dalam tiap proses }(2,5) \text {; } \\
\text { kombinasi lebih dari satu operasi yang sama } \\
\text { pada satu pekerjaan }(5) \text {; } \\
\text { kombinasi lebih dari satu operasi berbeda pada } \\
\text { suatu pekerjaan }(7,5) \text {; } \\
\text { progresif: lebih dari satu operasi yang } \\
\text { diselenggarakan paralel pada pekerjaan yang } \\
\text { berbeda pos (10) }\end{array}$ & \\
\hline 3 & $\begin{array}{l}\text { Tipe operasi yang } \\
\text { diselenggarakan }\end{array}$ & $\begin{array}{l}\text { Tiap poin 2,5: Pemotongan; } \\
\text { pembengkokkan; Penggambaran; } \\
\text { penekanan }\end{array}$ & \\
\hline 4 & $\begin{array}{l}\text { Rata-rata kesalahan yang terjadi } \\
\text { pada saat reparasi kapal }\end{array}$ & $0 \%(10) ; 6-10 \%(5) ; 25 \%(0)$ & \\
\hline 5 & $\begin{array}{l}\text { Frekuensi untuk perawatan } \\
\text { mesin }\end{array}$ & $\begin{array}{l}\text { Pemeliharaan preventif (10); pemeliharaan } \\
\text { dilakukan tetapi tidak secara periodik (5); } \\
\text { pemeliharaan pemulihan }(0)\end{array}$ & \\
\hline 6 & $\begin{array}{l}\text { Keahlian teknis operator yang } \\
\text { dibutuhkan untuk } \\
\text { mengoperasikan mesin }\end{array}$ & $\begin{array}{l}\text { Tidak perlu keahlian teknis (10); perlu tingkat } \\
\text { keterampilan tertentu (5); perlu keahlian } \\
\text { teknis yang spesifik (0) }\end{array}$ & \\
\hline 7 & $\begin{array}{l}\text { Pemeriksaan pada setiap } \\
\text { pekerjaan }\end{array}$ & $\begin{array}{l}\text { Pemeriksaan terkomputerisasi (10); } \\
\text { pemeriksaan manual (5); tidak diperlukan } \\
\text { pemeriksaan (0) }\end{array}$ & \\
\hline 8 & $\begin{array}{l}\text { Pengukuran pada setiap } \\
\text { pekerjaan }\end{array}$ & $\begin{array}{l}\text { Kompleks dan terkomputerisasi (10); sederhana } \\
\text { dan sketsa tangan (0) }\end{array}$ & \\
\hline 9 & $\begin{array}{l}\text { Tingkat keselamatan dan } \\
\text { keamanan kerja }\end{array}$ & Aman (10); wajar (5); bahaya (0) & \\
\hline
\end{tabular}

Sumber: Wiratmaja dan Ma'ruf, 2004 
Tabel 3 Matriks penilaian kriteria komponen humanware

\begin{tabular}{|c|c|c|c|}
\hline No. & Kriteria Komponen Humanware & Keterangan & Skor \\
\hline 1 & Kesadaran dalam tugas & $\begin{array}{l}\text { Sangat tinggi (10); rata-rata (5); sangat } \\
\text { rendah }(0)\end{array}$ & \\
\hline 2 & $\begin{array}{l}\text { Kesadaran kedisiplinan dan } \\
\text { tanggung jawab }\end{array}$ & $\begin{array}{l}\text { Sangat tinggi (10); rata-rata (5); sangat } \\
\text { rendah }(0)\end{array}$ & \\
\hline 3 & $\begin{array}{l}\text { Kreativitas dan inovasi dalam } \\
\text { menyelesaikan masalah }\end{array}$ & $\begin{array}{l}\text { Sangat tinggi (10); rata-rata (5); sangat } \\
\text { rendah (0) }\end{array}$ & \\
\hline 4 & $\begin{array}{l}\text { Kemampuan memelihara fasilitas } \\
\text { produksi }\end{array}$ & $\begin{array}{l}\text { Sangat tinggi (10); rata-rata (5); sangat } \\
\text { rendah (0) }\end{array}$ & \\
\hline 5 & Kesadaran bekerja dalam kelompok & $\begin{array}{l}\text { Sangat tinggi (10); rata-rata (5); sangat } \\
\text { rendah (0) }\end{array}$ & \\
\hline 6 & $\begin{array}{l}\text { Kemampuan untuk memenuhi } \\
\text { tanggal jatuh tempo }\end{array}$ & $100 \%(10) ;<50 \%(0)$ & \\
\hline 7 & $\begin{array}{l}\text { Kemampuan untuk menyelesaikan } \\
\text { masalah perusahaan }\end{array}$ & $\begin{array}{l}\text { Sangat tinggi (10); rata-rata (5); sangat } \\
\text { rendah (0) }\end{array}$ & \\
\hline 8 & Kemampuan bekerja sama & $\begin{array}{l}\text { Sangat tinggi (10); rata-rata (5); sangat } \\
\text { rendah (0) }\end{array}$ & \\
\hline 9 & Kepemimpinan & $\begin{array}{l}\text { Sangat tinggi (10); rata-rata (5); sangat } \\
\text { rendah }(0)\end{array}$ & \\
\hline
\end{tabular}

Sumber: Wiratmaja dan Ma'ruf, 2004

Tabel 4 Matriks penilaian kriteria komponen infoware

\begin{tabular}{clll}
\hline No. & \multicolumn{1}{c}{ Kriteria Komponen Infoware } & \multicolumn{1}{c}{ Keterangan } & \multicolumn{1}{c}{ Skor } \\
\hline 1 & Bentang informasi manajemen & $\begin{array}{l}\text { Bentang informasi termasuk perusahaan } \\
\text { eksternal (10); informasi sebagian (5); } \\
\text { bentang informasi tidak termasuk } \\
\text { perusahaan eksternal (0) }\end{array}$ \\
2 & $\begin{array}{l}\text { Perusahaan menginformasikan } \\
\text { masalah dan kondisi internal } \\
\text { dengan segera pada karyawan di } \\
\text { dalam perusahaan }\end{array}$ & Selalu (10); tidak pernah (0) \\
3 & $\begin{array}{l}\text { Jaringan informasi di dalam } \\
\text { perusahaan }\end{array}$ & Online (10); offline (0) \\
4 & $\begin{array}{l}\text { Prosedur untuk komunikasi antara } \\
\text { anggota di perusahaan }\end{array}$ & Mudah dan transparan (10); rumit (0) \\
5 & $\begin{array}{l}\text { Sistem informasi perusahaan untuk } \\
\text { mendukung aktivitas perusahaan }\end{array}$ & $\begin{array}{l}\text { Akses global (10); akses nasional (7.5); } \\
\text { akses lokal (5); tidak ada (0) }\end{array}$ \\
& $\begin{array}{l}\text { Penyimpanan dan pengambilan } \\
\text { informasi kembali }\end{array}$ & $\begin{array}{l}\text { Terkomputerisasi (10); manual (5); tidak } \\
\text { terarsip (0) }\end{array}$ \\
\hline
\end{tabular}

Sumber: Wiratmaja dan Ma'ruf, 2004 
Tabel 5 Matriks penilaian kriteria komponen orgaware

\begin{tabular}{|c|c|c|c|}
\hline No. & Kriteria Komponen Orgaware & Keterangan & Skor \\
\hline 1 & Otonomi perusahaan & $\begin{array}{l}\text { Otonomi penuh (10); kontrol dari } \\
\text { perusahaan induk (0) }\end{array}$ & \\
\hline 2 & Visi perusahaan & $\begin{array}{l}\text { Mengorientasi masa depan (10); tidak } \\
\text { ada (0) }\end{array}$ & \\
\hline 3 & $\begin{array}{l}\text { Kemampuan perusahaan dalam } \\
\text { menciptakan lingkungan yang } \\
\text { kondusif untuk mengadakan } \\
\text { perbaikan dan peningkatan } \\
\text { produktivitas }\end{array}$ & $\begin{array}{l}\text { Sangat tinggi (10); rendah (5); sangat } \\
\text { rendah }(0)\end{array}$ & \\
\hline 4 & $\begin{array}{l}\text { Kemampuan perusahaan untuk } \\
\text { memotivasi karyawan dengan } \\
\text { kepemimpinan yang efektif }\end{array}$ & $\begin{array}{l}\text { Sangat tinggi (10); rendah (5); sangat } \\
\text { rendah (0) }\end{array}$ & \\
\hline 5 & $\begin{array}{l}\text { Kemampuan perusahaan untuk } \\
\text { menyesuaikan diri dengan } \\
\text { lingkungan bisnis yang berubah dan } \\
\text { permintaan eksternal }\end{array}$ & $\begin{array}{l}\text { Sangat tinggi (10); rendah (5); sangat } \\
\text { rendah (0) }\end{array}$ & \\
\hline 6 & $\begin{array}{l}\text { Kemampuan perusahaan untuk } \\
\text { bekerjasama dengan supplier }\end{array}$ & $\begin{array}{l}\text { Sangat tinggi (10); rendah (5); sangat } \\
\text { rendah (0) }\end{array}$ & \\
\hline 7 & $\begin{array}{l}\text { Kemampuan perusahaan untuk } \\
\text { memelihara hubungan dengan } \\
\text { pelanggan }\end{array}$ & $\begin{array}{l}\text { Sangat tinggi (10); rendah (5); sangat } \\
\text { rendah }(0)\end{array}$ & \\
\hline 8 & $\begin{array}{l}\text { Kemampuan perusahaan untuk } \\
\text { mendapat dukungan sumberdaya } \\
\text { dari luar }\end{array}$ & $\begin{array}{l}\text { Sangat tinggi (10); rendah (5); sangat } \\
\text { rendah }(0)\end{array}$ & \\
\hline
\end{tabular}

Sumber: Wiratmaja dan Ma'ruf, 2004

Penentuan skor pada Tabel 2 sampai 5 adalah berdasarkan hasil identifikasi di lapangan dan wawancara. Setelah dilakukan penilaian pada masing-masing kriteria sebagaimana dipaparkan di atas, maka pengkajian SOTA dilakukan dengan menggunakan persamaan-persamaan sebagai berikut:

(1) Technoware

$\mathrm{ST}=\frac{1}{10} x\left[\frac{\sum t}{k}\right]$

$\mathrm{k}=$ jumlah kriteria komponen technoware

$\Sigma t=$ jumlah nilai kriteria technoware

(2) Humanware

$\mathrm{SH}=\frac{1}{10} x\left[\frac{\sum h}{k}\right]$

$\mathrm{k}=$ jumlah kriteria komponen humanware

$\Sigma \mathrm{h}=$ jumlah nilai kriteria humanware

(3) Infoware

$\mathrm{SI}=\frac{1}{10} x\left[\frac{\sum h}{k}\right]$ 
$\mathrm{k}=$ jumlah kriteria komponen infoware

$\Sigma \mathrm{h}=$ jumlah nilai kriteria infoware

(4) Orgaware

$\mathrm{SH}=\frac{1}{10} x\left[\frac{\sum h}{k}\right]$

$\mathrm{k}=$ jumlah kriteria komponen humanware

$\Sigma \mathrm{h}=$ jumlah nilai kriteria humanware

Berdasarkan nilai kecanggihan mutakhir dan SOTA, selanjutnya dihitung nilai kontribusi teknologi dengan formula sebagai berikut:

1. $\mathrm{T}=\frac{1}{9}[L T+S T(U T-L T)]$

2. $\mathrm{H}=\frac{1}{9}[L H+S H(U H-L H)]$

3. $\mathrm{I}=\frac{1}{9}[L I+S I(U I-L I)]$

4. $\mathrm{O}=\frac{1}{9}[L O+S O(U O-L O)]$

\section{Keterangan :}

$\mathrm{LT}=$ batas bawah technoware

$\mathrm{LI}=$ batas bawah infoware

$\mathrm{ST}=\mathrm{SOTA}$ technoware

$\mathrm{SI}=\mathrm{SOTA}$ infoware

$\mathrm{UT}=$ batas atas technoware

$\mathrm{UI}=$ batas atas infoware

$\mathrm{LH}=$ batas bawah humanware

$\mathrm{LO}=$ batas bawah orgaware

$\mathrm{SH}=\mathrm{SOTA}$ humanware

$\mathrm{SO}=\mathrm{SOTA}$ infoware

$\mathrm{UH}=$ batas atas humanware

$\mathrm{UO}=$ batas atas infoware

Penilaian intensitas kontribusi komponen teknologi menggunakan metode Simple Multi Attribute Rating Technique (SMART) berdasarkan Saaty (1991). Selanjutnya perhitungan nilai TCC menggunakan rumus berikut:

$$
\mathrm{TCC}=\mathrm{T}^{\beta \mathrm{t}} \times \mathrm{H}^{\beta \mathrm{h}} \times \mathrm{I}^{\beta \mathrm{i}} \times \mathrm{O}^{\beta \mathrm{o}}
$$

Keterangan :

TCC = technology contribution coefficient

$\mathrm{T}=$ nilai konstribusi komponen technoware

$\beta \mathrm{t} \quad=$ nilai intensitas konstribusi komponen technoware

$\mathrm{H}=$ nilai konstribusi komponen humanware

$\beta \mathrm{h} \quad=$ nilai intensitas konstribusi komponen humanware

I = nilai konstribusi komponen infoware

$\beta \mathrm{i}=$ nilai intensitas konstribusi komponen infoware

$\mathrm{O}=$ nilai konstribusi komponen orgaware

Bo $\quad=$ nilai intensitas konstribusi komponen orgaware 
Nilai TCC dari suatu perusahaan menunjukkan kontribusi teknologi dari operasi transformasi total terhadap output. Menurut Wiraatmaja dan Ma'ruf (2004) nilai dari TCC dapat menunjukkan level teknologi pada suatu perusahaan seperti yang disajikan pada Tabel 6.

Tabel 6 Penilaian kualitatif TCC

\begin{tabular}{cl}
\hline Nilai TCC & \multicolumn{1}{c}{ Klasifikasi } \\
\hline $0<$ TCC $\leq 0,3$ & Tradisional \\
$0,3<$ TCC $\leq 0,7$ & Semi modern \\
$0,7<$ TCC $\leq 1,0$ & Modern \\
\hline
\end{tabular}

Sumber: Wiratmaja, Masni dan Diawati (2004)

\section{HASIL DAN PEMBAHASAN}

Penilaian tingkat teknologi galangan kapal PT. Proskuneo Kadarusman dilakukan menggunakan model teknometrik. Model teknometrik mendefinisikan koefisien kontribusi teknologi (Technology Contribution Coeffisien/TCC) dalam suatu fasilitas transformasi di galangan kapal PT. Proskuneo Kadarusman. Kriteria komponen teknologi menggunakan metode scoring berdasarkan penilaian subyektif terhadap kriteria komponen technoware, humanware, infoware dan orgaware. Terdapat lima langkah untuk mengestimasikan nilai TCC, yang akan dijelaskan dalam sub-sub bab berikut.

\section{Estimasi derajat kecanggihan}

Penilaian derajat kecanggihan menunjukkan kecanggihan dari setiap komponen teknologi yang ada di galangan yang mengacu pada Tabel 1 . Berdasarkan hasil penilaian derajat kecanggihan diperoleh nilai pada masing-masing komponen seperti terlihat pada Tabel 7.

Tabel 7 Penilaian batas bawah dan batas atas komponen teknologi

\begin{tabular}{lcc}
\hline \multirow{2}{*}{ Komponen } & \multicolumn{2}{c}{ Limit } \\
\cline { 2 - 3 } & Lower & Upper \\
\hline Technoware & 1 & 6 \\
Humanware & 1 & 7 \\
Infoware & 1 & 6 \\
Orgaware & 1 & 5 \\
\hline
\end{tabular}

Berdasarkan tinjauan di lapangan, dihasilkan bahwa fasilitas produksi yang terkait dengan komponen technoware terdiri dari fasilitas manual (1) dan fasilitas penggunaan khusus (6). Komponen humanware memiliki kemampuan mengoperasikan (1) dan ada yang memiliki kemampuan mengadaptasi (7). Komponen infoware diketahui bahwa pada galangan kapal terdapat fakta pengenalan (1) dan fakta pemahaman (6). Komponen orgaware pada galangan kapal memiliki kerangka kerja usaha (1) dan kerangka kerja bertindak berani (5) untuk memperluaskan jaringan ikatan perusahaan.

\section{Pengkajian Mutakhir atau State of the Art (SOTA)}

Berdasarkan hasil kuisioner diperoleh nilai SOTA pada masing-masing komponen technoware, humanware, infoware dan orgaware. Hasil penilaian subyektif terhadap kriteria komponen teknologi, secara rinci disajikan pada Tabel 8, 9, 10 dan 11. 
Tabel 8 Matriks hasil penilaian kriteria komponen technoware

\begin{tabular}{|c|c|c|c|}
\hline No. & Kriteria Komponen Technoware & Keterangan & Skor \\
\hline 1 & Tipe mesin yang digunakan & Mekanik & 5 \\
\hline 2 & Tipe proses yang diterapkan & $\begin{array}{l}\text { Kombinasi lebih dari satu operasi } \\
\text { berbeda pada suatu pekerjaan }\end{array}$ & 7,5 \\
\hline 3 & Tipe operasi yang diselenggarakan & $\begin{array}{l}\text { Penggambaran, pemotongan, dan } \\
\text { pembengkokan }\end{array}$ & 7,5 \\
\hline 4 & $\begin{array}{l}\text { Rata-rata kesalahan yang terjadi pada } \\
\text { saat reparasi kapal }\end{array}$ & $<10 \%$ & 5 \\
\hline 5 & Frekuensi untuk perawatan mesin & $\begin{array}{l}\text { Rutin, namun service besar tidak } \\
\text { dilakukan secara periodik }\end{array}$ & 7,5 \\
\hline 6 & $\begin{array}{l}\text { Keahlian teknis operator yang } \\
\text { dibutuhkan untuk mengoperasikan } \\
\text { mesin }\end{array}$ & $\begin{array}{l}\text { Hampir semua mesin tidak perlu } \\
\text { keahlian teknis }\end{array}$ & 8 \\
\hline 7 & Pemeriksaan pada setiap pekerjaan & Pemeriksaan manual & 5 \\
\hline 8 & Pengukuran pada setiap pekerjaan & Sederhana dan sketsa tangan & 4 \\
\hline \multirow[t]{4}{*}{9} & $\begin{array}{l}\text { Tingkat keselamatan dan keamanan } \\
\text { kerja }\end{array}$ & Aman & 9 \\
\hline & & Jumlah & 58,5 \\
\hline & & Rata-rata & 6,5 \\
\hline & & SOTA & 0,65 \\
\hline
\end{tabular}

Tabel 9 Matriks hasil penilaian kriteria komponen humanware

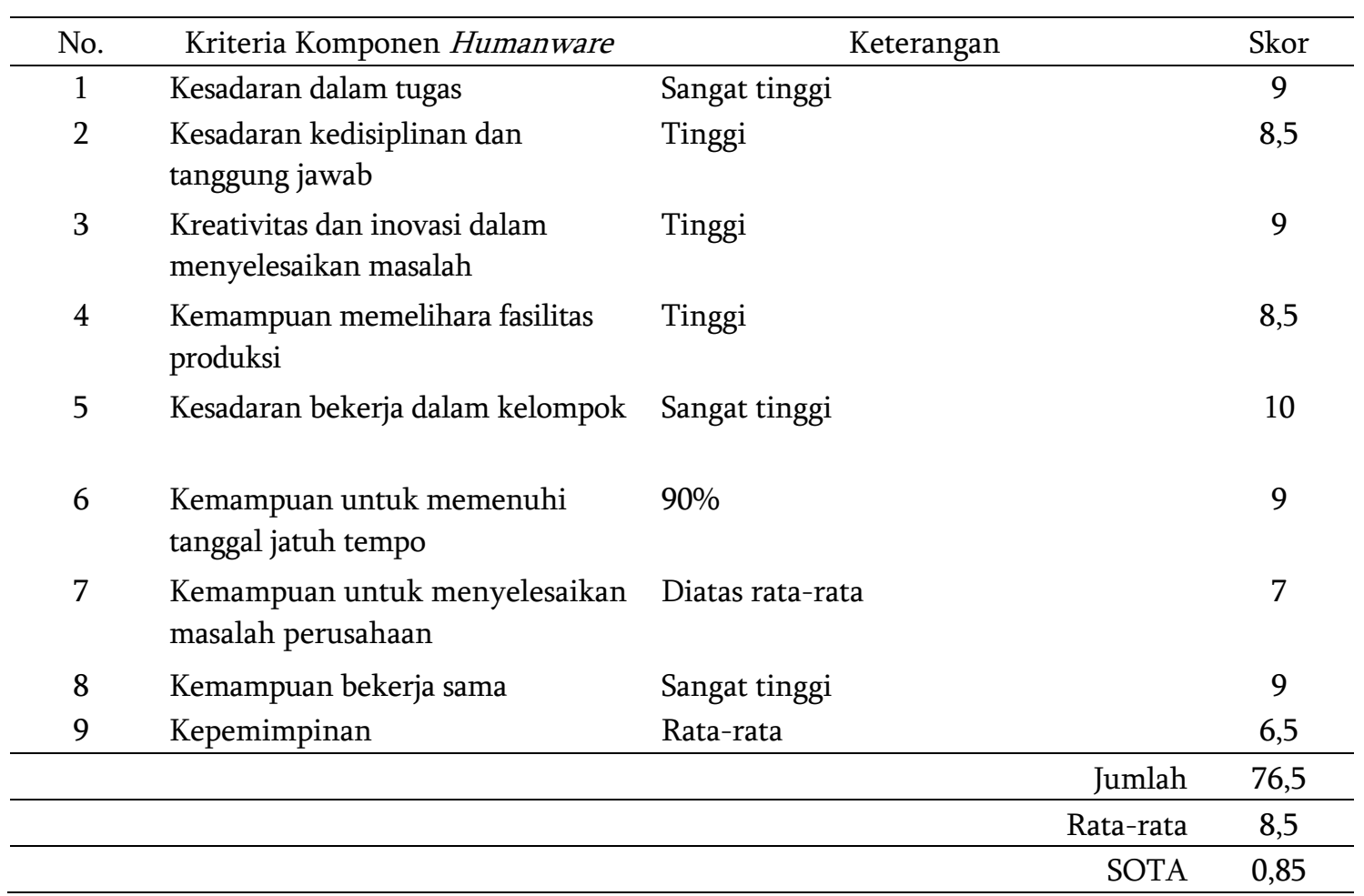


Tabel 10 Matriks hasil penilaian kriteria komponen infoware

\begin{tabular}{|c|c|c|c|}
\hline No. & Kriteria Komponen Infoware & Keterangan & Skor \\
\hline 1 & Bentang informasi manajemen & $\begin{array}{l}\text { Bentang informasi sebagian termasuk } \\
\text { perusahaan eksternal }\end{array}$ & 7 \\
\hline 2 & $\begin{array}{l}\text { Perusahaan menginformasikan } \\
\text { masalah dan kondisi internal } \\
\text { dengan segera pada karyawan di } \\
\text { dalam perusahaan }\end{array}$ & $\begin{array}{l}\text { Pada umumnya perusahaan } \\
\text { menginformasikan pada karyawan }\end{array}$ & 8 \\
\hline 3 & $\begin{array}{l}\text { Jaringan informasi di dalam } \\
\text { perusahaan }\end{array}$ & Offline & 0 \\
\hline 4 & $\begin{array}{l}\text { Prosedur untuk komunikasi antara } \\
\text { anggota di perusahaan }\end{array}$ & Mudah dan transparan & 10 \\
\hline 5 & $\begin{array}{l}\text { Sistem informasi perusahaan untuk } \\
\text { mendukung aktivitas perusahaan }\end{array}$ & Akses lokal & 3 \\
\hline \multirow[t]{4}{*}{6} & $\begin{array}{l}\text { Penyimpanan dan pengambilan } \\
\text { informasi kembali }\end{array}$ & Tidak semua data terkomputerisasi & 7,5 \\
\hline & & Jumlah & 35,5 \\
\hline & & Rata-rata & 5.917 \\
\hline & & SOTA & 0,592 \\
\hline
\end{tabular}

Tabel 11 Matriks hasil penilaian kriteria komponen orgaware

\begin{tabular}{|c|c|c|c|}
\hline No. & Kriteria Komponen Orgaware & Keterangan & Skor \\
\hline 1 & Otonomi perusahaan & Diatur sendiri & 9 \\
\hline 2 & Visi perusahaan & Mengorientasi masa depan & 10 \\
\hline 3 & $\begin{array}{l}\text { Kemampuan perusahaan dalam } \\
\text { menciptakan lingkungan yang } \\
\text { kondusif untuk mengadakan } \\
\text { perbaikan dan peningkatan } \\
\text { produktivitas }\end{array}$ & Sangat tinggi & 10 \\
\hline 4 & $\begin{array}{l}\text { Kemampuan perusahaan untuk } \\
\text { memotivasi karyawan dengan } \\
\text { kepemimpinan yang efektif }\end{array}$ & Sangat rendah & 0 \\
\hline 5 & $\begin{array}{l}\text { Kemampuan perusahaan untuk } \\
\text { menyesuaikan diri dengan } \\
\text { lingkungan bisnis yang berubah dan } \\
\text { permintaan eksternal }\end{array}$ & Rendah & 3 \\
\hline 6 & $\begin{array}{l}\text { Kemampuan perusahaan untuk } \\
\text { bekerjasama dengan supplier }\end{array}$ & Sangat tinggi & 10 \\
\hline 7 & $\begin{array}{l}\text { Kemampuan perusahaan untuk } \\
\text { memelihara hubungan dengan } \\
\text { pelanggan }\end{array}$ & Sangat tinggi & 10 \\
\hline \multirow[t]{4}{*}{8} & $\begin{array}{l}\text { Kemampuan perusahaan untuk } \\
\text { mendapat dukungan sumberdaya } \\
\text { dari luar }\end{array}$ & Sangat tinggi & 10 \\
\hline & & & 62 \\
\hline & & & 7,75 \\
\hline & & & 0,775 \\
\hline
\end{tabular}




\section{Kontribusi Komponen Teknologi}

Penilaian kontribusi komponen teknologi diperoleh dengan menggunakan nilai batasan derajat kecanggihan dengan nilai state of the art (SOTA). Hasil perhitungan nilai kontribusi komponen dapat dilihat pada Tabel 12.

Tabel 12 Nilai kontribusi komponen teknologi

\begin{tabular}{lcccc}
\hline \multirow{2}{*}{ Komponen } & \multicolumn{2}{c}{ Limit } & \multirow{2}{*}{ SOTA } & \multirow{2}{*}{ Nilai Kontribusi } \\
\cline { 2 - 3 } & Lower & Upper & & 0.4722 \\
\hline Technoware & 1 & 6 & 0,65 & 0.6778 \\
Humanware & 1 & 7 & 0,85 & 0.4398 \\
Infoware & 1 & 6 & 0,592 & 0.4556 \\
Orgaware & 1 & 5 & 0,775 & \\
\hline
\end{tabular}

Berdasarkan nilai kontribusi komponen di atas, kontribusi komponen teknologi dapat diurutkan sebagai berikut : $\mathrm{H}>\mathrm{T}>\mathrm{O}>\mathrm{I}$. Nilai kontribusi orgaware dan infoware perlu dilakukan peningkatan, yaitu dengan cara mengkaji ulang penugasan di struktur organisasi, adanya pembenahan struktur organisasi, menyusun data secara terkomputerisasi, membuat sistem jaringan komunikasi online dan hal lainnya yang dapat meningkatkan nilai kontribusi komponen orgaware dan infoware.

\section{Pengkajian Intensitas Kontribusi Komponen}

Pengkajian intensitas konttribusi komponen teknologi dilakukan dengan menggunakan Proses Hierarki Analitik (Analytical Hierarchy Prosess). Nilai intensitas kontribusi komponen teknologi disajikan pada Tabel 13.

Tabel 13 Nilai intensitas kontribusi komponen

\begin{tabular}{lc}
\hline Komponen & Intensitas kontribusi \\
\hline Technoware & 0.4617 \\
Humanware & 0.3001 \\
Infoware & 0.0694 \\
Orgaware & 0.1688 \\
\hline
\end{tabular}

Nilai intensitas masing-masing komponen galangan tersebut sebagai berikut: technoware, humanware, orgaware dan infoware. Nilai consistency ratio sebesar 0,07 menunjukkan bahwa penilaian tingkat kepentingan yang dilakukan telah konsisten karena nilai tersebut $\leq 0,1$.

\section{Koefisien Kontribusi Teknologi (TCC)}

Berdasarkan hasil perhitungan estimasi derajat kecanggihan, SOTA, kontribusi komponen dan intensitas kontribusi komponen diperoleh nilai koefisien kontribusi teknologi (technology contribution coefficient) yang disebut TCC. Nilai TCC sebesar 0,5178 menunjukkan bahwa tingkat teknologi di galangan kapal PT. Proskuneo Kadarusman berada pada tingkat semi modern sesuai dengan klasifikasi penilaian TCC pada Tabel 6.

\section{KESIMPULAN DAN SARAN}

Berdasarkan nilai TCC dari galangan kapal PT. Proskuneo Kadarusman sebesar menunjukkan bahwa teknologi di galangan tersebut berada pada klasifikasi semi modern. Hal ini menunjukkan bahwa galangan kapal mampu bersaing dalam menghadapi jumlah kapal di wilayah DKI Jakarta.

\section{DAFTAR PUSTAKA}

Hasan. 2002. Pokok-pokok Materi Penelitian dan Aplikasinya. Bogor (ID): Ghalia Indonesia. 
[KKP] Kementrian Kelautan dan Perikanan Direktorat Jendral Perikanan Tangkap. 2010. Pelabuhan Perikanan Samudera Nizam Zachman Jakarta.

Nazaruddin. 2008. Manajemen Teknologi. Yogyakarta (ID): Graha Ilmu. hlm 87- 104.

Saaty TL. 1991. Pengambilan Keputusan Bagi Para Pemimpin. Proses Hierarki Analitik untuk Pengambilan Keputusan dalam Situasi yang Komplek (Terjemahan dari Decisions Making for Leader the Analytical Hierarchy Process for Decisions in Complex Word). Jakarta (ID): PT. Pustaka Binaman Pressindo.

Widjaja S. 1996. Manajemen Produksi untuk Industri Perkapalan. Surabaya (ID): Fakultas Teknologi Kelautan, Institut Teknologi Surabaya.

Wiratmaja IW dan Ma'ruf A. 2004. The Assesment of Technology in Supporting Industry Located at Tegal Industrial Park. Proceddings of Marine Transportation Engineering Seminar. Osaka University (JP). 